\title{
STUDI KOMPARASI METODE SEGMENTASI PARU-PARU PADA CITRA CT-SCAN AKSIAL
}

\author{
Made Satria Wibawa ${ }^{1}$, I Made Agus Wirahadi Putra ${ }^{2}$ \\ Program Studi Sistem Informasi \\ STMIK STIKOM BALI \\ Denpasar, Indonesia \\ e-mail: satria.wibawa@stikom-bali.ac.id ${ }^{1}$, wirahadi@stikom-bali.ac.id ${ }^{2}$
}

\begin{abstract}
Abstrak
Kanker paru dapat diobati jika diagnosis dini dilakukan. Diagnosis dapat dilakukan menggunakan modalitas citra Computed Tomography (CT). Diagnosis kanker paru melalui citra CT dilakukan oleh tenaga medis. Untuk membantu diagnosis kanker, tenaga medis dapat dibantu dengan Computer Assisted Diagnosis (CAD). Dalam CAD, tahapan pertama yang paling penting adalah segmentasi citra paru-paru. Penelitian ini melakukan studi komparasi metode segmentasi citra CT paru-paru. Terdapat tiga metode segmentasi yang digunakan, yaitu Otsu, K-Means dan Fuzzy C-Means. Ketiga metode tersebut diujikan pada 28 citra CT paru-paru aksial. Proses evaluasi menggunakan metrik akurasi, true negative rate dan true positive rate. Berdasarkan nilai yang diperoleh dari ketiga parameter evaluasi tersebut, ketiga metode segmentasi dapat memberikan hasil segmentasi yang mendekati citra ground truth. Namun, dilihat dari sebaran hasil nilai ketiga parameter evaluasi yang didapatkan dari seluruh citra, metode Otsu memberikan hasil yang segmentasi yang secara keseluruhan baik dibandingkan kedua metode segmentasi lainnya. Nilai akurasi, TPR dan TNR yang diperoleh metode Otsu rata-rata bernilai lebih dari 0.98 , tidak seperti kedua metode lainnya yang mengalami penurunan di parameter TPR.
\end{abstract}

Kata kunci: paru-paru, CT, segmentasi citra, fuzzy c-means, k-means

\begin{abstract}
Lung cancer can be treated if an early diagnosis is conducted. Diagnosis can be performed by examining Computed Tomography (CT) images of lung. Lung cancer diagnosis with CT images is performed by medical personnel. To help cancer diagnosis, medical personnel can be assisted with Computer Assisted Diagnosis (CAD). In CAD, the most important first step is the segmentation of lung images. This study conducted a comparative study of image segmentation methods in pulmonary CT image. There were three segmentation methods used, namely Otsu, K-Means and Fuzzy C-Means. The three methods were tested on 28 axial lung CT images. In this study, the evaluation process used three metrics i.e. accuracy, true negative rate and true positive rate. Based on the values obtained from the three evaluation parameters, the three segmentation methods give segmentation results that similar to ground truth image. However, based on the distribution results of three evaluation parameters obtained from all images, the Otsu method is better in overall compared to the other two segmentation methods. Accuracy rates, TPR and TNR obtained by the Otsu method averaged more than 0.98, unlike the other two methods which experienced a decrease in the TPR parameters.
\end{abstract}

Keywords : pulmonary, CT, image segmentation, fuzzy c-means, $k$-means

\section{PENDAHULUAN}

Kanker merupakan permasalahan kesehatan yang utama di berbagai belahan dunia. Salah satu tipe kanker, yaitu kanker paru-paru memiliki tingkat kematian tertinggi diantara tipe kanker lainnya. Pasien dengan kanker paru-paru tidak merasakan gejala di awal stadium kanker, namun dapat menyebabkan kematian jika tidak dideteksi dengan cepat. Untuk itu diperlukan 
diagnosa yang cepat dan akurat untuk menangani penyakit kanker[1].

Computed tomography (CT) scan merupakan salah satu teknik pencitraan yang dapat digunakan untuk diagnosa kanker paru-paru. Jika dibandingkan dengan x-ray, citra CT-scan dapat menampilkan jaringan lunak serta membentuk citra 3-D dan CT-scan lebih murah dibandingkan MRI. CT-scan dapat menampilkan citra tulang, jaringan lunak dan pembuluh darah dalam waktu yang bersamaan. Alat untuk mengakuisisi citra CT disebut CT-scanner. CT scanner terdiri dari berbagai macam spesifikasi, karena itu citra CT memiliki tingkat kecerahan yang bervariasi. Sensor elektronik CT scanner dapat menghasilkan derau pada citra, derau ini dapat menurunkan kualitas citra serta mempersulit analisa citra lebih lanjut.

Kualitas yang beragam mengharuskan kualitas citra CT distandarisasi, standarisasi citra CT terdiri dari tahapan Region of Interest (ROI) dan penghilangan derau. Beberapa metode untuk mengurangi derau telah diajukan pada penelitian sebelumnya, diantaranya penapisan Gaussian, penapisan median dan penapisan mean. Diagnosa kanker paru-paru dapat dilakukan jika citra CT telah memenuhi standar kualitas yang seragam.

Kanker paru-paru dapat didiagnosa dengan cara analisa citra CT-scan secara seksama. Tahapan awal analisa CT-scan adalah segmentasi dari anatomi paru-paru. Segmentasi pada paru-paru dapat berupa segmentasi untuk area paru-paru, lobes paru-paru, fissure dan anomali pada paruparu[2]. Segmentasi area paru-paru merupakan tahapan pertama dan paling penting dalam serangkaian proses segmentasi. Segmentasi area paru-paru bertujuan untuk memisahkan area yang merupakan paru-paru dengan area lainnya seperti tulang dan jaringan lunak lainnya

Beberapa penelitian telah dilakukan untuk segmentasi area paru-paru pada citra CT-scan. Pengolahan citra atau image processing telah banyak digunakan untuk segmentasi citra CT-scan paru-paru. Kombinasi dari thresholding, region growing dan deteksi tepi digunakan oleh Mesanovic, dkk untuk segmentasi area paru-paru. Thresholding digunakan untuk segmentasi toraks dari latar belakang citra, region growing digunakan untuk segmentasi area paru-paru kemudian deteksi tepi digunakan untuk membuat masking citra[3]. Fuzzy entropy dan segmentasi berbasis morfologi digunakan oleh Jaffar, dkk untuk mensegmentasi paru-paru dari latar belakang pada citra CT-scan. Metode tersebut menggunakan informasi yang terkandung dalam citra dan menerapkan kombinasi teknik pengolahan citra dan logika fuzzy[4].

Dengan melihat pentingnya segmentasi area paru-paru sebagai tahapan awal dalam deteksi kanker paru-paru menggunakan computer aided diagnosis, maka penelitian ini akan melakukan studi komparasi untuk menemukan metode segmentasi area paru-paru yang optimal pada citra CT-scan. Beberapa metode yang dikomparasikan dalam penelitian ini adalah metode thresholding, watershed, region growing dan clustering. Sebelum proses segmentasi dilakukan pada citra, terlebih dahulu dilakukan proses peningkatan kualitas citra yang meliputi peningkatan kontras dan penghilangan derau. Metode segmentasi hasil studi komparasi diharapkan akan dapat menghasilkan citra segmentasi yang mendekati gold standard dari citra segmentasi CT-scan.

\section{METODE PENELITIAN}

Dalam penelitian ini terdapat beberapa tahapan untuk melakukan segmentasi area paru-paru. Data terdiri dari 28 citra CT paru-paru, dimana setiap citra mewakili subjek yang berbeda. Sumber data tersebut adalah Data Science Bowl 2017 yang diperoleh dari situ Kaggle (https://www.kaggle.com/c/data-sciencebowl-2017/data). Tahapan pertama terdiri dari peningkatan kontras citra dengan koreksi gamma, penapisan derau. Tahapan pertama bertujuan untuk meningkatkan kualitas citra CT. Tahapan berikutnya dilakukan proses segmentasi citra, terdapat tiga metode segmentasi yang digunakan pada penelitian ini. Metode tersebut adalah metode Otsu, Fuzzy C-Means dan K- 
Means. Untuk menilai keberhasilan masingmasing metode segmentasi akan dilakukan perbandingan dengan citra CT dengan citra gold standard. Perbandingan dilakukan secara kuantitatif menggunakan metrik akurasi, true positive rate (TPR) dan true negative rate (TNR). Secara garis besar, tahapan penelitian ini dapat diilustrasikan pada Gambar 1.

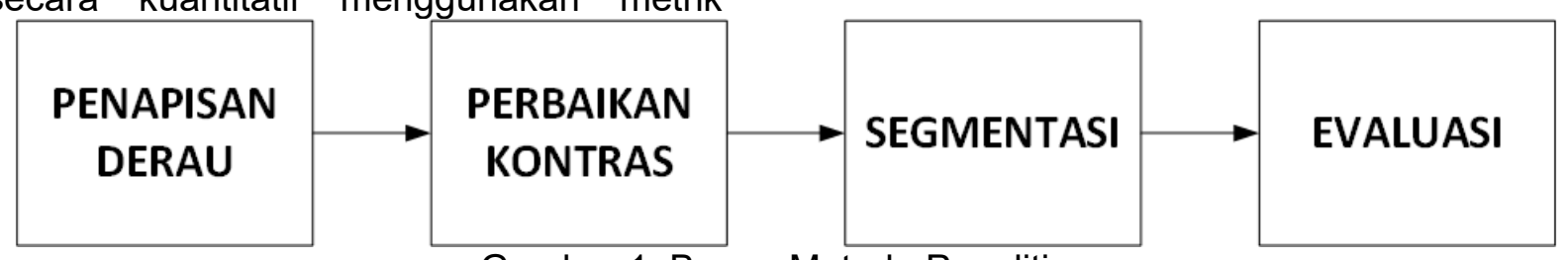

\subsection{Pra-pengolahan}

Tahapan pra-pengolahan merupakan proses pertama dalam serangkaian tahapan penelitian ini. Tahapan ini terdiri dari perbaikan kontras dan penapisan derau. Pra-pengolahan bertujuan untuk memperbaiki kualitas citra sehingga dapat analisis citra dapat dilakukan dengan baik.

a. Perbaikan Kontras

Kontras merupakan perbedaan tingkat keabuan pada citra yang dapat membantu kita membedakan objek yang berbeda atau latar belakang dalam sebuah citra. Perbaikan kontras dalam penelitian ini berguna untuk membantu membedakan area paru-paru dengan area selain paru-paru pada citra CT.

Metode yang digunakan untuk perbaikan kontras adalah metode perbaikan gamma. Perumusan perbaikan gamma dapat dilihat pada Persamaan $\mathrm{XX}$

$i_{\text {out }}=c i_{\text {in }}^{\gamma}$

Dimana $i_{\text {out }}$ adalah intensitas hasil perbaikan kontras, $c$ adalah konstanta, $i_{\text {in }}$ adalah intensitas citra masukan dan $\gamma$ adalah variabel gamma dengan rentang 0 1.

b. Penapisan Derau

Derau (noise) dalam citra merupakan variasi acak dari tingkat keabuan dalam citra dan biasanya dampak dari derau sinyal elektronis. Derau dapat dihasilkan sensor dan srikut dari mesin CT. Derau dapat mengganggu proses analisis citra, untuk itu diperlukan proses penapisan untuk mengurangi jumlah derau dalam citra.

Dalam penelitian ini digunakan metode penapisan derau Guided, Median dan Gaussian.

\subsection{Segmentasi}

Segmentasi adalah proses utama yang dilakukan pada penelitian ini. Segmentasi bertujuan untuk memisahkan area paru-paru dengan area latarnya. Pemisahan ini akan menghasilkan citra paru-paru tanpa objek lainnya. Citra tersebut akan membantu tenaga medis untuk melakukan analisis lebih lanjut.

Terdapat tiga metode segmentasi yang diujikan pada penelitian ini, yaitu metode Otsu, metode Fuzzy C-Means dan $\mathrm{K}-\mathrm{means}$.

a. Otsu

Metode thresholding merupakan metode segmentasi yang sederhana dan cepat. Dari sekian banyak metode dalam thresholding, metode Otsu merupakan salah satu metode yang adaptif dan efektif serta telah banyak digunakan untuk segmentasi citra.

b. Fuzzy C-Means

Fuzzy C-Means merupakan metode klastering yang dapat mengelompokkan sebuah intensitas piksel ke dalam dua atau lebih klaster. Fuzzy C-Means menghasilkan derajat keanggotaan satu intensitas piksel ke semua klaster. Klaster akhir akan ditentukan berdasarkan urutan 
tertinggi dari nilai derajat keanggotaan yang dihasilkan. Metode ini teknik unsupervised yang telah berhasil diterapkan pada bidang astronomi, geologi, pencitraan medis, pengenalan target dan segmentasi gambar. Untuk proses minimalisasi fungsi obyektif pada jarak antara intensitas piksel dengan pusat klaster dapat digunakan rumus pada Persamaan 2[4], [5].

$\min J(U, H)=$

$\sum_{i=k}^{n} \sum_{k=1}^{c} u_{i k}^{m}\left(\left\|x_{i}-h_{k}\right\|\right)_{A}$

c. K-Means

Metode ini menerapkan metode kmeans untuk membagi citra ke dalam klaster-klaster untuk mendapatkan wilayah yang hampir homogen (seragam). Teknik ini menggabungkan intensitas citra ke dalam beberapa pusat klaster terdekat. Untuk menggabungkan intensitas ke pusat, jarak antar intensitas dengan pusat klaster harus ditentukan. Jarak tersebut biasanya dinotasikan dengan simbol $d$ yang dapat dilihat pada Persamaan 3[6] .

$d=\left\|p(x, y)-c_{k}\right\|$

\subsection{Evaluasi}

a. Evaluasi Pra-pengolahan

Penapisan derau dapat menghilangkan informasi yang penting atau kualitas citra. Metode penapisan derau sebisa mungkin harus dapat mempertahankan kualitas citra dalam meminimalisir derau dalam citra. Untuk itu diperlukan proses penilaian metode penapisan derau dalam menentukan metode penapisan derau yang terbaik. Structural Similarity Index Measure (SSIM) merupakan salah satu metrik yang digunakan untuk mengukur kemiripan antar dua buah citra. SSIM dapat menilai visual citra berdasarkan persepsi sistem visual manusia. SSIM memiliki rentang nilai 0-1. Dimana angka 0 berarti tidak ada korelasi antar citra dan 1 berarti antara dua citra sama[7]. Untuk mengukur SSIM dari sinyal $x$ dan $y$, diperlukan perbandingan dari luminansi ( $l$ ), kontras (c) dan struktur $(s)$ dua sinyal tersebut. Secara ringkas, ketiga pengukuran tersebut dalam bentuk SSIM dapat ditulis dalam Persamaan 4.

$\operatorname{SSIM}(x, y)=\left[l(x, y)^{\alpha} \cdot c(x, y)^{\beta}\right.$. $\left.s(x, y)^{\gamma}\right]$

Dimana $\alpha, \beta$ dan $\gamma$ merupakan bobot dari masing-masing parameter perbandingan.

b. Evaluasi Segmentasi

Dalam penelitian ini, evaluasi hasil segmentasi menggunakan metrik akurasi, True Positive Rate (TPR) dan True Negative Rate (TNR). Gambar 2 menjelaskan cara evaluasi menggunakan akurasi, TPR dan TNR. Misalkan terdapat dua citra, yaitu citra ground truth dan citra segmentasi. Citra ground truth digambarkan dengan lingkaran merah, sedangkan citra segmentasi digambarkan dengan lingkaran hijau. Untuk melakukan evaluasi, kedua jenis citra tersebut dibandingkan dengan piksel yang bersesuaian. Citra ground truth diperoleh dari seorang dokter pulmonologi.

$$
\begin{aligned}
& \text { Akurasi }=\frac{T P+T N}{T P+T N+F N+F P} \\
& T P R=\frac{T P}{T P+F N} \\
& T N R=\frac{T N}{T N+F P}
\end{aligned}
$$




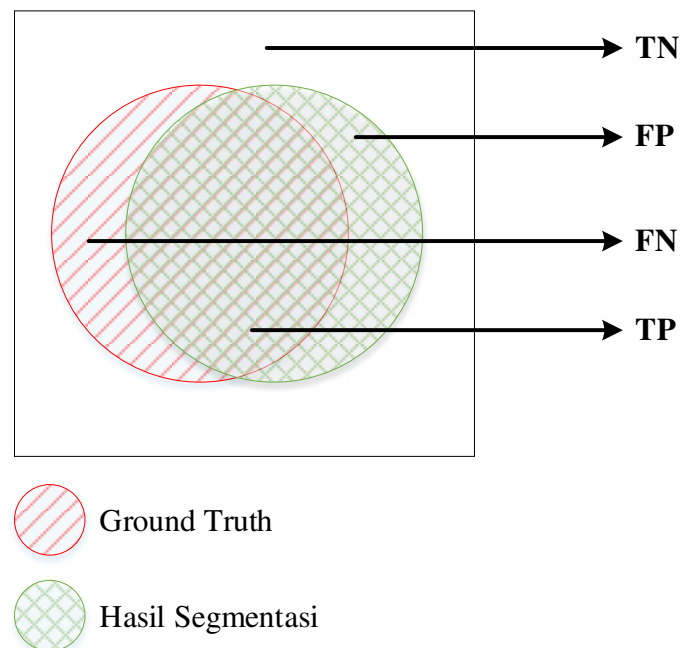

\section{Gambar 2. Evaluasi Hasil Segmentasi Citra \\ HASIL DAN PEMBAHASAN \\ Data yang didapatkan dari repositori Kaggle berasal dari beragam mesin Computed Tomography (CT) dengan spesifikasi yang berbeda. Perbedaan spesifikasi dan cara pengaturan alat CT \\ peningkatan kecerahan citra. Pada penelitian ini, peningkatan kecerahan citra dilakukan dengan menggunakan metode koreksi gamma. Metode koreksi gamma menggunakan parameter $c$ sebesar 2 dan $\gamma$ sebesar 0.1 .} menghasilkan citra CT yang berbeda pula, terutama dalam tingkat kecerahan citra. Untuk itu, perlu dilakukan proses

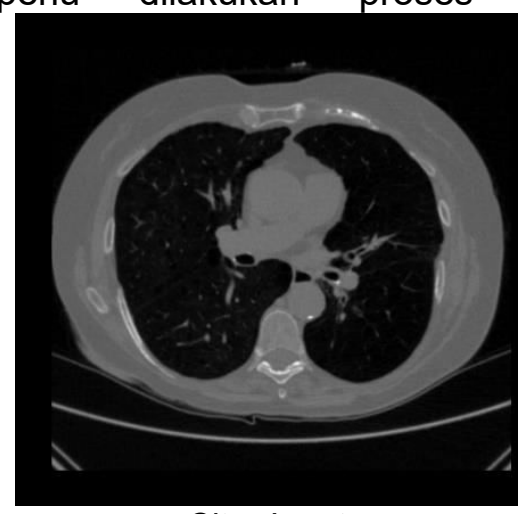

Citra Input

Gambar 3. Tahapan Perbaikan Kontras Citra CT

Hasil peningkatan kecerahan citra dapat dilihat pada Gambar 3. Terlihat pada Gambar 3, kontras pada citra awal tidak terlalu tajam. Pada citra CT paru dengan kontras yang baik, objek pada tubuh akan memiliki tingkat keabuan berbeda yang dapat mudah dibedakan. Setelah kontras pada citra CT diperbaiki, perbedaan antara objek pada citra CT terlihat lebih jelas. Selain masalah kontras, pada citra CT umumnya ditemui permasalahan derau

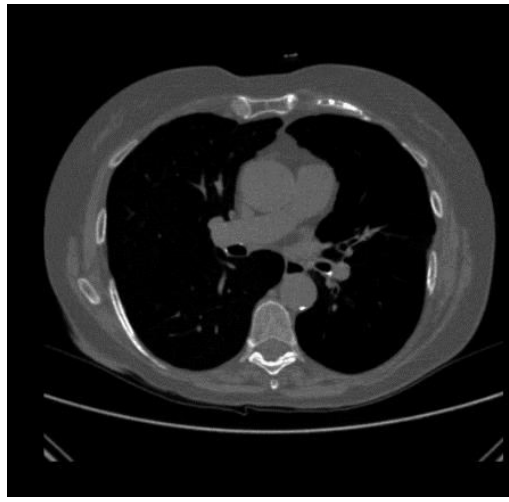

Citra Hasil Koreksi Gamma

pada citra. Derau dapat menurunkan kualitas citra dan dapat mempersulit hasil segmentasi. Untuk mengatasi derau, umunya dilakukan proses penapisan dengan tapis aras rendah. Pada penelitian ini digunakan tiga jenis penapisan, hal ini untuk mencari metode penapisan yang cocok dengan citra input. Metode penapisan tersebut adalah tapis Gaussian, tapis Guided dan tapis Median. 


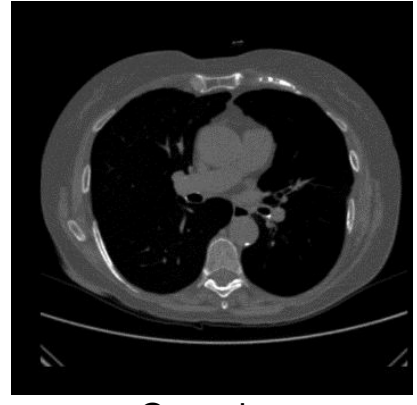

Gaussian

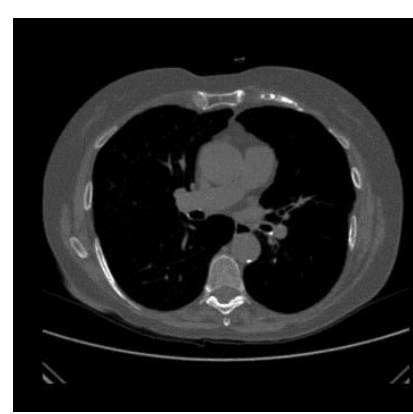

Citra Input

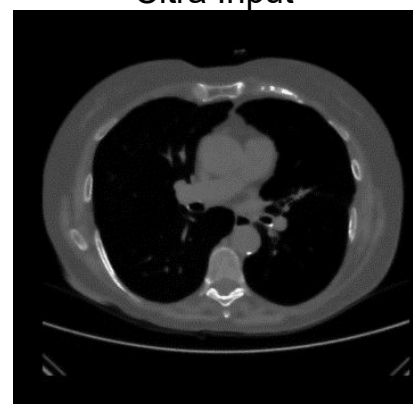

Guided

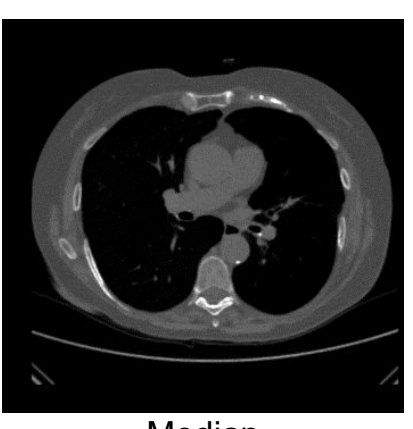

Median

Gambar 4. Hasil Penapisan Derau pada Citra

Hasil penapisan dapat dilihat secara visual pada Gambar 4. Secara visual, tidak terlihat ada perbedaan yang mencolok pada hasil penapisan di antara ketiga metode penapisan. Untuk mengevaluasi metode terbaik yang akan digunakan pada proses penapisan derau, kami melakukan pengujian dengan parameter Structural Similarity Index (SSIM). Hasil penilaian metode penapisan dengan SSIM dapat dilihat pada grafik batang Gambar 5. Untuk diketahui, SSIM memiliki rentangan nilai dari -1 hingga 1 , dimana nilai 1 berarti struktur antar citra sama dan -1 berarti struktur antar dua citra beda sama sekali. Nilai SSIM semakin mendekati nilai 1 maka semakin baik, artinya proses penapisan derau tidak terlalu banyak mengubah struktur citra namun cukup efektif untuk mereduksi derau. Metode penapisan Guided, Median dan Gaussian secara berturut-turut ditunjukkan dengan grafik batang berwarna biru, oranye dan abu-abu. Secara umum tapis Gaussian memberikan nilai yang lebih tinggi dibandingkan tapis Guided dan Median. Rata-rata nilai SSIM tapis Gaussian sebesar 0.9965, sedangkan nilai rata-rata SSIM tapis Guided dan Median secara berturut-turut sebesar 0.9402 dan 0.9795. Oleh karena nilai SSIM tapis Gaussian yang lebih tinggi dibandingkan dua tapis tersebut, maka untuk penapisan derau pada penelitian ini menggunakan metode Gaussian.

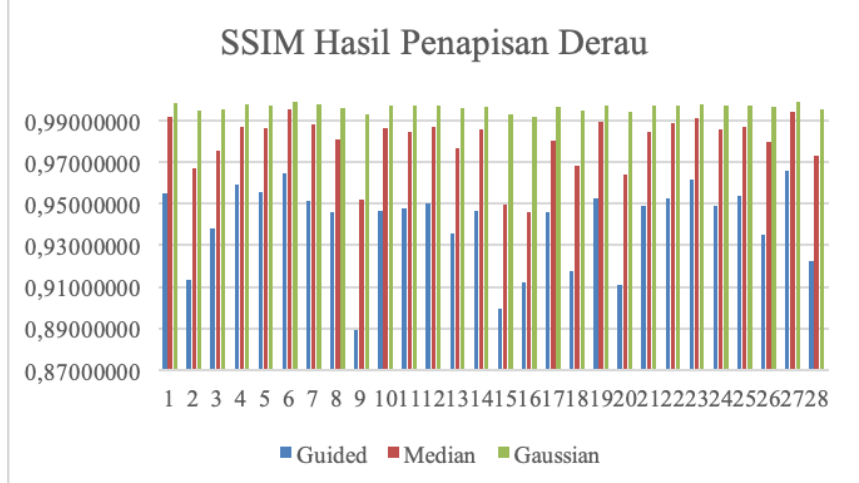

Gambar 5. Evaluasi Penapisan Derau Berdasarkan SSIM 
Tahapan pra-pengolahan segmentasi yang meliputi perbaikan kontras dan penghilangan derau telah dilakukan pada proses sebelumnya dan hasilnya cukup baik. Segmentasi dilakukan pada semua citra CT paru menggunakan ketiga metode segmentasi, yaitu metode Otsu, Fuzzy CMeans dan Kmeans. salah satu contoh hasil segmentasi diperlihatkan pada Gambar 6. Untuk menilai kinerja hasil masing-masing metode segmentasi dilakukan perbandingan citra hasil segmentasi dengan citra ground truth. Citra ground truth merupakan hasil segmentasi yang benar. Area paru pada citra ground truth diperoleh berdasarkan konsultasi dengan dokter terkait. Pada contoh hasil segmentasi yang ditunjukkan pada Gambar 6 , terlihat ketiga metode segmentasi dapat membentuk area segmentasi yang menyerupai citra ground truth.

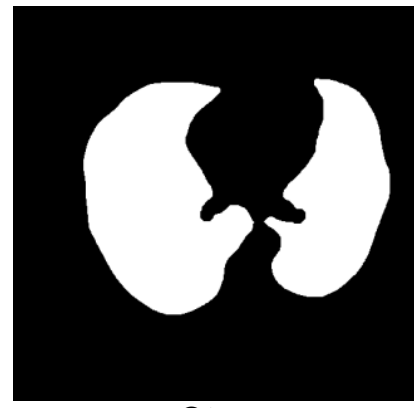

Otsu

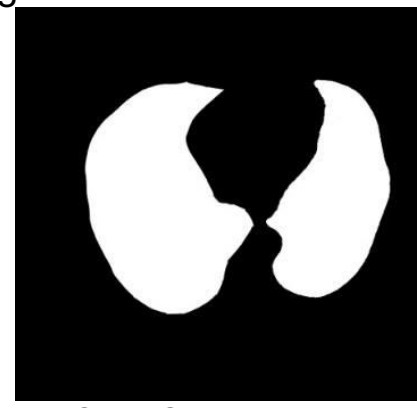

Citra Ground Truth

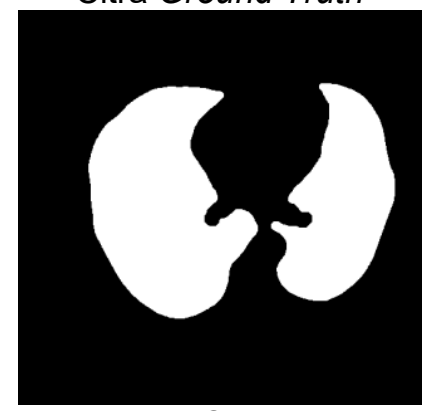

Fuzzy C-Means

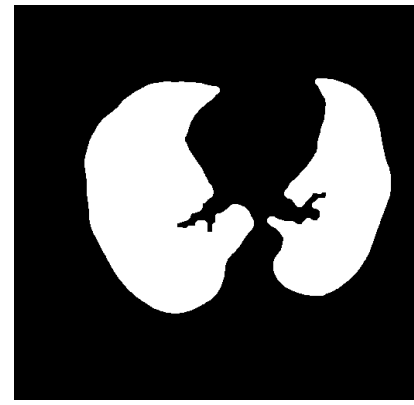

K-Means

Gambar 6. Perbandingan Bentuk Citra Ground Truth dengan Hasil Segmentasi

Penilaian hasil segmentasi secara visual sulit dilakukan, karena kita sulit mengukur secara pasti berapa persentase area yang seharusnya menjadi paru-paru dan latar citra secara pasti. Untuk itu akan dilakukan pengujian secara kuantitatif, yaitu dengan cara menghitung berapa persentase dari area hasil segmentasi yang benar dikenali. Misalnya jika satu piksel pada citra segmentasi dikenali sebagai area paru-paru dan piksel yang sama juga merupakan area paru-paru pada citra ground truth, maka piksel tersebut merupakaan hasil segmentasi yang benar. Persentase piksel dari citra hasil segmentasi yang benar/salah yang dijadikan acuan ketepataan hasil
Untuk melakukan hal tersebut, terlebih dahulu kita harus mengetahui tepi citra segmentasi dengan tepi citra ground truth pada gambar yang sama. Pada Gambar 7 terlihat perbandingan tepi citra hasil segmentasi dengan citra ground truth. Tepi citra hasil segmentasi ditandai dengan garis berwarna merah, sedangkan tepi citra ground truth ditandai dengan warna hijau. Pada contoh citra pertama, terlihat hasil segmentasi Otsu mirip dengan citra hasil Fuzzy C-Means. Namun, citra hasil Kmeans terlihat jauh berbeda dengan kedua metode segmentasi yang lainnya. Pada contoh citra pertama, hasil Otsu dan Fuzzy C-Means paling mendekati dengan citra ground truth. 


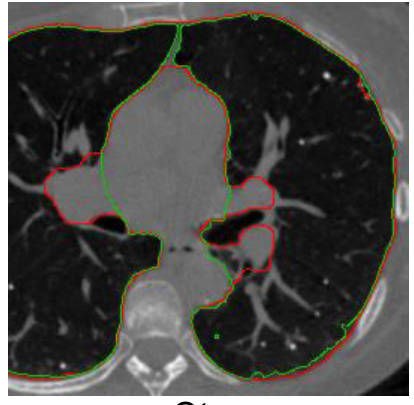

Otsu

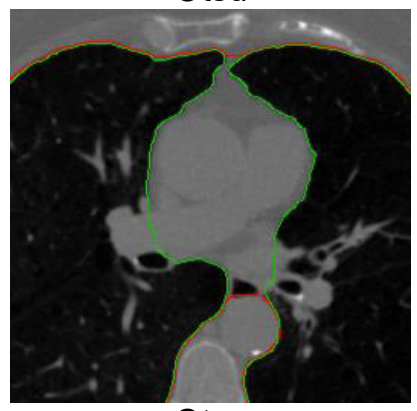

Otsu

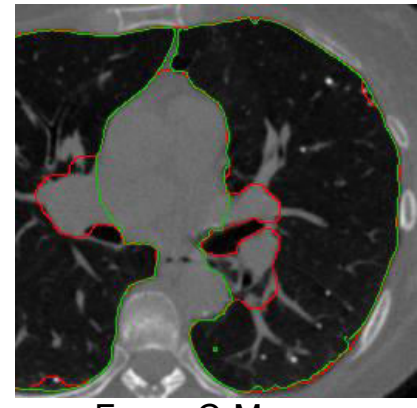

Fuzzy C-Means

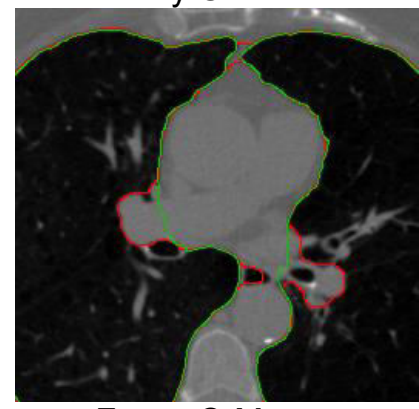

Fuzzy C-Means

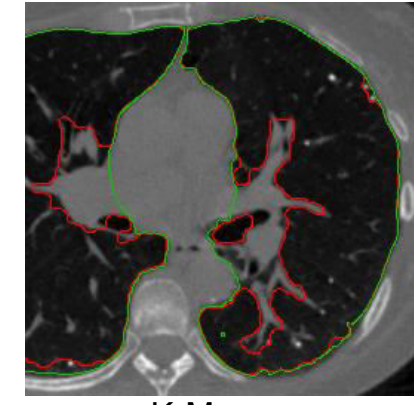

K-Means

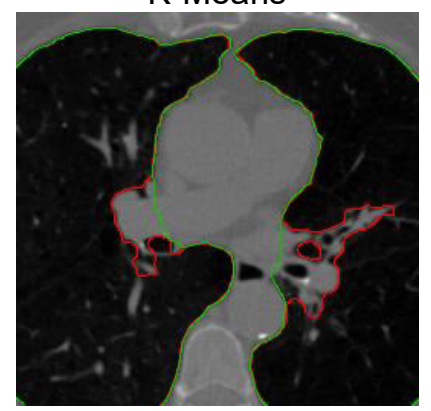

K-Means

Gambar 7. Perbandingan Tepi Citra Hasil Segmentasi dan Citra

Citra kedua hasil segmentasi pada Gambar 7 memberikan hasil yang berbeda dengan citra pertama. Pada citra kedua, metode Otsu gagal memberikan hasil yang sesuai dengan citra ground truth. Hasil segmentasi Otsu tidak dapat memisahkan area paru-paru dengan area di sekeliling paru-paru. Tidak ada satu metode segmentasi yang dapat memberikan hasil yang baik pada semua citra CT paru yang digunakan.

Dari perbandingan hasil segmentasi dan citra ground truth, dapat diambil beberapa parameter evaluasi, diantaranya Akurasi, TNR (True Negative Rate) dan TPR (True Positive Rate). Gambar 8 menyajikan rerata ketiga parameter tersebut. Metode segmentasi yang baik akan menghasilkan nilai akurasi, TPR dan TNR yang tinggi.

Dilihat dari rerata nilai akurasi, metode Fuzzy C-Means memberikan hasil segmentasi terbaik. Rerata akurasi yang didapatkan oleh metode Fuzzy C-Means bernilai sebesar 0.9922, sedangkan rerata nilai Otsu dan K-means yang diperoleh secara berturut-turut sebesar 0.9913 dan 0.9888 . Dilihat dari rerata nilai TPR, metode Otsu mengungguli kedua metode segmentasi lainnya. Nilai rerata TPR yang diperoleh Otsu sebesar 0.9832, sedangkan nilai TPR yang diperoleh oleh K-Means dan Fuzzy C-Means secara berturut-turut sebesar 0.9480 dan 0.9704. Untuk parameter TNR, metode K-Means memberikan nilai rerata tertinggi di antara metode segmentasi lainnya dengan nilai sebesar 0.9990. Nilai rerata TNR yang diperoleh Otsu dan Fuzzy C-Means sebesar 0.9927 dan 0.9971 .

Nilai akurasi yang tinggi tidak cukup untuk menandakan bahwa metode segmentasi tersebut baik. Hasil segmentasi yang baik akan menghasilkan nilai akurasi TPR dan TNR yang tinggi dan berimbang. Jika salah satu nilai dari ketiga parameter tersebut rendah, hasil segmentasi tidak Contohnya, citra dengan nilai TNR jauh lebih kecil dibandingkan TPR menandakan area latar dominan menutupi objek utama dan sebaliknya. 


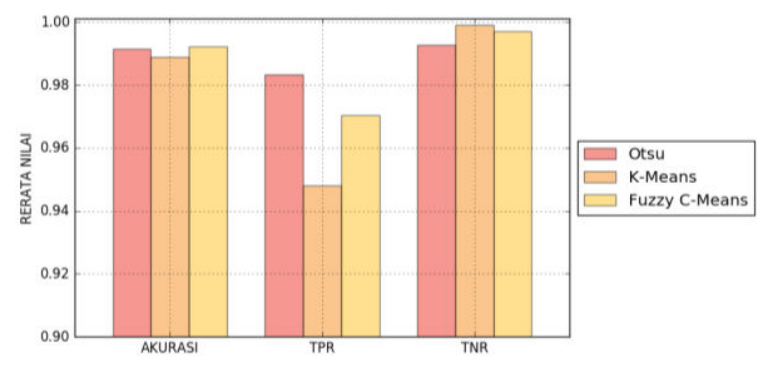

Gambar 8. Rerata Nilai Akurasi, TPR \& TNR

Namun, nilai rerata saja tidak cukup untuk mengevaluasi kinerja metode segmentasi. Kita harus mengetahui hasil segmentasi secara keseluruhan, karena bisa saja ada beberapa citra yang memiliki hasil segmentasi yang buruk. Untuk itulah pada Gambar 9 disajikan diagram box plot, diagram ini dapat memberikan informasi statistik mengenai nilai segmentasi secara keseluruhan. Jika dilihat dari sebaran nilai akurasi, TPR dan TNR ketiga metode segmentasi memberikan hasil yang baik. Hal ini dapat dilihat dari nilai terendah ketiga metriks evaluasi. Nilai terendah yang dicapai semuanya diatas nilai 0.9 .

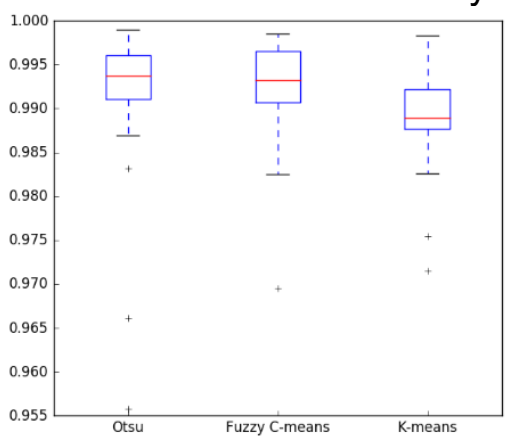

Akurasi

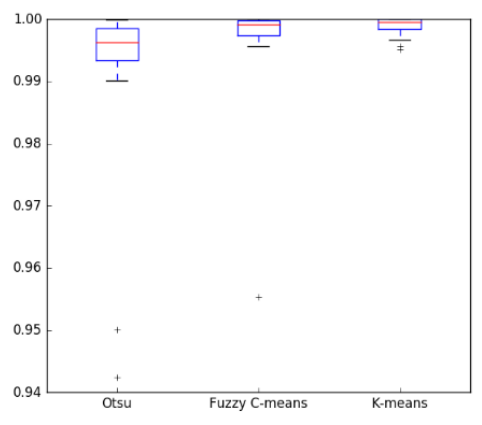

True Negative Rate

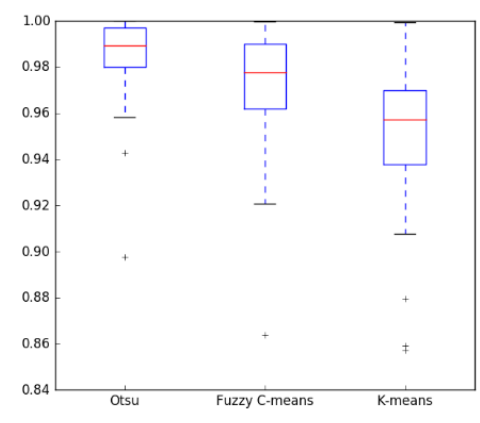

True Positive Rate

Gambar 9. Box Plot Evaluasi Segmentasi

\section{KESIMPULAN DAN SARAN}

Penelitian ini bertujuan untuk melakukan studi komparasi metode segmentasi citra paru dengan modalitas CT bagian aksial. Segmentasi merupakan tahapan awal untuk analisis citra CT dalam diagnosa penyakit.

Dalam penelitian ini proses segmentasi citra CT terdiri dari tahapan perbaikan kontras, penapisan derau, segmentasi dan evaluasi. Terdapat tiga jenis metode segmentasi yang digunakan pada penelitian ini, yaitu Otsu, Fuzzy CMeans dan K-Means. Evaluasi metode segmentasi dilakukan menggunakan metrik akurasi, True Positive Rate (TPR) dan True Negative Rate (TNR). Citra paru yang digunakan sejumlah 28 citra, setiap citra mewakili orang yang berbeda.

Berdasarkan nilai dari metrik evaluasi, metode Otsu sedikit lebih unggul dibandingkan metode Fuzzy C-Means dan 
K-Means. Penelitian berikutnya dapat mengembangkan segmentasi lebih lanjut, misalnya untuk deteksi nodul tumor.

\section{UCAPAN TERIMAKASIH}

Terimakasih kami ucapkan kepada Kementerian Riset, Teknologi dan Pendidikan Tinggi Republik Indonesia untuk pendanaan dalam skema Penelitian Dosen Pemula. Berkat pendanaan dalam skema riset tersebut, maka penelitian ini dapat diselesaikan

\section{REFERENSI}

[1] P. Kamra, R. Vishraj, S. Gupta, dan others, "Performance comparison of image segmentation techniques for lung nodule detection in CT images," dalam Signal Processing, Computing and Control (ISPCC), 2015 International Conference on, 2015, hlm. 302-306.

[2] K. Devaki dan V. MuraliBhaskaran, "Study of computed tomography images of the lungs: A survey," dalam Recent Trends in Information Technology (ICRTIT), 2011 International Conference On, 2011, hlm. 837-842.

[3] N. Mesanovic, M. Grgic, H. Huseinagic, M. Males, E. Skejic, dan
M. Smajlovic, "Automatic CT image segmentation of the lungs with region growing algorithm," dalam 18th International Conference on Systems, Signals and Image Processing-IWSSIP, 2011, hlm. 395-400.

[4] M. A. Jaffar, A. Hussain, dan A. M. Mirza, "Fuzzy entropy based optimization of clusters for the segmentation of lungs in CT scanned images," Knowl. Inf. Syst., vol. 24, no. 1, hlm. 91-111, 2010.

[5] C. Bai, D. Dhavale, dan J. Sarkis, "Complex investment decisions using rough set and fuzzy c-means: An example of investment in green supply chains," Eur. J. Oper. Res., vol. 248, no. 2, hlm. 507-521, Jan 2016.

[6] N. Dhanachandra, K. Manglem, dan Y. J. Chanu, "Image Segmentation Using $\mathrm{K}$-means Clustering Algorithm and Subtractive Clustering Algorithm," Procedia Comput. Sci., vol. 54, hlm. 764-771, 2015.

[7] A. Hore dan D. Ziou, "Image Quality Metrics: PSNR vs. SSIM," dalam 2010 20th International Conference on Pattern Recognition, Istanbul, Turkey, 2010, hlm. 2366-2369. 